\title{
Anti-HIV Effect of Liposomes Bearing CXCR4 Receptor Antagonist N15P
}

\author{
Yingxia Zhao, Hanxiao Sun*, Xiuying Li, Xuemei Mo and Guang Zhang \\ College of Pharmacy, Jinan University, GuangZhou, GuangDong Province, China, 510632
}

*For correspondence: Email: fangcaobi860317@163.com; Tel: +86 15201543769

Received: 22 June 2013

Revised accepted: 28 July 2013

\begin{abstract}
Purpose: To evaluate lymphatic system targeting and inhibitory ability of N15P nano-liposomal preparation (naLipo-N15P) of CXCR4 receptor antagonist in HIV infection.

Methods: Chemotactic and chemotaxic inhibition activity assays were used to analyze the biological activity of naLipo-N15P. The anti-HIV potential of NaLipo-N15P in vitro was evaluated when NaLipoN15P combined with the peripheral blood mononuclear cells of Macaca fascicularis which carry the Simian immunodeficiency virus. Furthermore, the anti-HIV potential in vivo of NaLipo-N15P was evaluated by the plasma concentration and tissue distribution (Ki)

Results: The half-maximal inhibitory concentration of naLipo-N15P binding to CXCR4 as an antagonist in competition with SDF-1a was 1.89 pM while Ki was 2.4 pM. Viral load was $289 \pm 45$. NaLipo- N15P majorly accumulated in liver and spleen.

Conclusion: When N15P is encapsulated into nano-liposomes, it not only retains specific binding to CXCR4 and facilitates cell-type-specific targeting of nano-liposomes to PBMCs with high CXCR4 expression, but also shows enhanced anti-HIV effect. Therefore, we propose that naLipo-N15P as a CXCR4 antagonist will play an important role in inflammation and blocking of HIV infection.
\end{abstract}

Keywords: Antagonist, CXCR4, Liposomes, Receptor, Inflammation, HIV

Tropical Journal of Pharmaceutical Research is indexed by Science Citation Index (SciSearch), Scopus, International Pharmaceutical Abstract, Chemical Abstracts, Embase, Index Copernicus, EBSCO, African Index Medicus, JournalSeek, Journal Citation Reports/Science Edition, Directory of Open Access Journals (DOAJ), African Journal Online, Bioline International, Open-J-Gate and Pharmacy Abstracts

\section{INTRODUCTION}

Chemokines are a family of small $(8-10 \mathrm{kDa})$ proteins that act as chemoattractants by signaling through their receptors and activating target cells. CXCR4 is a G-coupled heptahelical receptor that first drew attention as a major coreceptor for the entry of HIV(human immunodeficiency virus)[1]. The CXCR4 and its only characterized chemokine ligand, stromal cell-derived factor-1 (SDF-1), are important in HIV infection [2]. A variety of compounds that target CXCR4 to prevent HIV infection have been developed [2]. Viral macrophage inflammatory protein (VMIP)-II, a chemokine encoded by human herpes virus 8 , displays diverse interactions with both $\mathrm{CC}$ and $\mathrm{CXC}$ chemokine receptors and inhibits HIV-1 entry mediated through CCR3, CCR5, and CXCR4 [3]. Comparison of the amino acid sequences of VMIP-II and other human chemokines reveals that the N-terminus of VMIP-II has little homology with either CC or CXC chemokines, whereas the other regions of VMIP-II share a high sequence similarity with CC chemokines such as MIP-1 $\alpha$ and MIP-1 $\beta$ [4]. Thus, it is conceivable that the unique N-terminal sequence of VMIP-II may confer a biological function.

Zhou et al [5] found that the N-terminus of VMIPII is essential for its function via CXCR4. In contrast to the full-length protein, a peptide corresponding to residues 1-21 derived from the $\mathrm{N}$-terminus of VMIP-II was shown to bind strongly 
to CXCR4. However, the spatial conformation of residues $1-21$ of VMIP-II is extremely variable due to its poor stability, leading to variations in its biological activity. Nevertheless, a multiple sequence alignment between VMIP-II and the CXCR4 receptor-binding factor showed that the $\mathrm{N}$-terminal 1-15 peptide has the same specific binding to CXCR4. Furthermore, the N-terminal 1-15 peptide of VMIP-II was more stable (the instability index (II) was 28.79 , the residues $1-21$ of vMIP-II was 57.29). To test this hypothesis, a synthetic peptide derived from the N-terminus $1-$ 15 of VMIP-II was synthesized (LGASWHRPDKCCLGY, designated as N15P).

At present, nanotechnology plays an important role in the development of new types of therapeutic interventions [6]. Systemically administered nano-therapeutics have been shown to enhance the therapeutic index of drugs, either by increasing the drug concentration at the site of interest and/or by decreasing exposure in healthy tissues. Therefore, in order to improve the antagonistic activity of N15P against CXCR4 and to target prevention of HIV infection in inflammatory tissue with high CXCR4 expression in vivo, the peptideas encapsulated into nanoliposomes, named naLipo-N15P.

\section{EXPERIMENTAL}

\section{Materials}

Human PBMCs were separated from whole blood by centrifugation using Ficoll density gradient centrifugation. Lymphocyte separation medium was purchased from Sigma (USA). The recombinant human chemokine SDF-1a was lyophilized and dissolved as 1 or $2.5 \mu \mathrm{g} / \mu \mathrm{L}$ stock solutions in sterile phosphate-buffered saline (PBS) and stored at $-20{ }^{\circ} \mathrm{C}$ in aliquots. $\mathrm{Na}^{125} \mathrm{I}$ was purchased from R\&D Systems Inc. Cell culture media plus $10 \%$ fetal bovine serum were also purchased from R\&D Systems Inc (USA). The $\mathrm{Y}$ - radioimmunoassay counter and RPMI 1640 containing $0.5 \%$ fetal bovine serum was purchased from Sigma. Macaca fascicularis bearing simian immunodeficiency virus (SIV) were obtained from our laboratory (We have acquired approval from the JinNan University Ethical Committee in accordance with "Principles of Laboratory Animal Care". The peptide $\left(\mathrm{NH}_{2}-\right.$ LGASW HRPDKCCLG Y -COOH, named N15P) was synthesized by Ji Nuo Tai Biological Technology Co., Ltd. Xian, China), using standard fluorenylmethyloxycarbonyl chemistry and purified by high-performance liquid chromatography, sequence confirmation was by mass spectroscopy; the purity was $98 \%$, and the molecular weight was 1705.9.

\section{Radioiodination}

The N15P was radioiodinated with $\mathrm{Na}^{125}$ I using the chloramine $\mathrm{T}$ method and acetylated using acetic anhydride [7]. The labeling rate and radiochemical purity were $80 \pm 5.12$ and $89.00 \pm$ $3.67 \%$, respectively. The specific activity was $1142 \mu \mathrm{Ci} / \mathrm{nM}$,

\section{Preparation of naLipo-N15P}

The nano liposomes were prepared using the reverse rotary evaporator combined with ultrasound. Lecithin and cholesterol (ratio, 5:1) were dissovled in diethyl ether in a centrifuge tube by vortexing in a $\mathrm{WH}-2$ miniature vortex, then transferred to a round bottom rotating flask. While stirring the mixture of lecithin cholesterol and diethyl ether, N15P was added to the mixture. The round bottom rotating flask was placed in a water bath (temperature, $45^{\circ} \mathrm{C}$ ) to completely volatilize the ether. The pale yellow layer in the bottom of the rotating roundbottomed flask was dissolved with $10 \mathrm{ml}$ diethyl ether again, and $10 \mathrm{ml}$ double -distilled water was added. The mixed liquid was poured into a beaker for ultrasonic vibration for 5 minutes. The sonicated liquid mixture was poured into a round bottom flask for rotary evaporation for $35 \mathrm{~min}$. The liquid mixture converted into a milky white powder, named nano-liposome. The results of particle size analysis and potential detection of the nano liposome showed that its shape is circular, and evenly distributed; the average particle diameter was $80.3 \pm 11.37 \mathrm{~nm}$; zeta potential was $29.37 \pm 3.30 \mathrm{mV}$, and they remained fairly stable after storage in a refrigerator for 1 month. After 4 months of storage at $-20{ }^{\circ} \mathrm{C}$, the encapsulation efficiency was still $56.73 \pm 0.22$. The encapsulation efficiency of naLipo-N15P at $-20{ }^{\circ} \mathrm{C}$ was higher and more stable than at either $4{ }^{\circ} \mathrm{C}$ or $25^{\circ} \mathrm{C}$ (46.65 \pm 0.19 and $20.52 \pm 0.17$ respectively).

\section{Chemotactic activity assay}

MTT assay is sensitive for the detection of the cytotoxicity of N15P for peripheral blood mononuclear ells (PBMCs), and thus the method can assess drug toxicity in normalhuman cells, provide a measure of chemotaxis. MTT assay was used to determine the chemotactic activity of healthy human PBMCs treated with naLipoN15Ps and by N15P. Different concentrations of naLipo-N15P and N15P (10x dilutions from 1000 $\mathrm{ng} \mathrm{mL}^{-1}$ to $0.1 \mathrm{ng} \mathrm{mL}^{-1}$ with RPMl 1640) were added to PBMCs $\left(1 \times 10^{6}\right.$ cells $\left.\mathrm{mL}^{-1}\right)$. RPMI 1640 without serum solution was used as the blank control; the same amount of SDF-1a was used as the positive control. The absorbance of each 
well at $490 \mathrm{~nm}$ was measured using a microplate reader (DNM-9606, ShangHai BILON). The resulting cell viability was calculated as described previously [8].

\section{Chemotactic inhibition activity assay}

To detect the chemotactic inhibition activity of naLipo-N15P, we tested nine different physiological chemokine receptors on PBMCs (IL-8, MIP-3a, MIP-3 $\beta$, MCP-1, exotaxin-2, IP-10, I-309, SDF-1a, purchased from Sigma). RPMI 1640 was the blank control, $10 \mathrm{ng} / \mathrm{mL}$ SDF-1a in RPMI 1640 as the positive control, and different concentrations of naLipo-N15P and N15P $(0.1,1$, 10,100 , and $1000 \mathrm{ng} / \mathrm{ml}$ ) in chemotactic buffer as the experimental group. Chemotaxis experiments were conducted in a 24-well Transwell unit, incubated for $2 \mathrm{~h}$ at $37^{\circ} \mathrm{C}$ in $5 \%$ $\mathrm{CO}^{2}$. Cell density was counted using a hemocytometer, and the data analyzed using SPSS Statistics software, version17.0.

\section{Competitive binding to CXCR4}

In order to study receptor-ligand binding, competitive binding experiments were performed using a single concentration $(0.5 \mathrm{nM})$ of ${ }^{125}$ $\mathrm{N} 15 \mathrm{P}$ and ${ }^{125} \mathrm{I}-$ naLipo-N15P in the presence of increasing concentrations of unlabeled ligand in a $100-\mu \mathrm{L}$ final volume of binding buffer (50 nM Hepes, $\mathrm{pH} 7.4,1 \mathrm{nM} \mathrm{CaCl}, 5 \mathrm{nM} \mathrm{MgCl} 2,0.1 \%$ bovine serum albumin) containing $1 \times 10^{6}$ PBMCs. Nonspecific binding was determined by the addition of $100 \mathrm{nM}$ unlabeled naLipo-N15P or N15P, respectively. Samples were incubated for $60 \mathrm{~min}$ at room temperature. The incubation was terminated by separating the cells from the binding buffer by centrifugation and washing once with $500 \mu \mathrm{L}$ cold binding buffer. Bound ligand was quantified by counting $y$ emissions.

In ligand competition experiments, the concentration of ${ }^{125}$ I-N15P or ${ }^{125}$ I- naLipo-N15P and ${ }^{125} \mathrm{I}-\mathrm{SDF}-1 \mathrm{a}$ were fixed at $0.5 \mathrm{nmol} / \mathrm{L}$, and unlabeled N15P or naLipo-N15P were added to the PBMC suspension. Samples were incubated for $60 \mathrm{~min}$ at room temperature. The incubation was terminated by separating the cells from the binding buffer by centrifugation and washing once with $500 \mu \mathrm{L}$ of cold binding buffer. Samples were washed with PBS two times by centrifugation at $3000 \times \mathrm{g}$ for 3 min to wash away free ${ }^{125}$ I-N15P , ${ }^{125}$ I-naLipo-N15P and ${ }^{125}$ I-SDF1a. Bound ligand was quantified by counting $Y$ emissions.

Detection of specific binding: The experimental group was treated with $200 \mathrm{ng} / \mathrm{mL}$ naLipo-N15P and N15P. SDF-1 $\alpha$ was used as the positive control group and human serum albumin as negative control group. The cells were then treated with $100 \mathrm{ng} / \mathrm{mL}$ CXCR4-FITCmonoclonal fluorescent antibody, after incubated for $2 \mathrm{~h}$. The coverslip and slide were sealed with a solution of glycerol and PBS. The values were determined by laser scanning confocal microscopy (LSCM) with absorbance/emission wavelengths of $480 / 550 \mathrm{~nm}$.

\section{Pharmacokinetic properties of naLipo-N15P}

Equal amounts of naLipo-N15P (1 mg/kg) or N15P were injected into the tail vein of Macaca fascicularis infected with SIV. The blood was collected at various time points $(15,30,45,60$, $75,90,120,150,180,240$, and $300 \mathrm{~min}$ ) to detect the plasma concentration. Ninety minutes after the injection of naLipo-N15P, or 75 min after the injection of N15P, the heart, kidney, spleen, lung, and liver were removed, and the associated adipose tissue and connective tissue were cleaned. After washing with PBS, the surface water was drained using filter paper. The right amount of tissue was weighed, and an equal volume of saline was added, followed by highspeed homogenization. The homogenate was centrifuged at $2000 \times \mathrm{g}$ for $15 \mathrm{~min}$ and sterilized by passing through a microporous membrane $(0.22 \mu \mathrm{m})$. The supernatant was placed in a $4^{\circ} \mathrm{C}$ refrigerator to be used for tissue distribution studies.

\section{Effect of naLipo-N15P on SIV infection}

The blood of Macaca fascicular infected with SIV was extracted, and the PBMCs separated. The same amount of naLipo-N15P (1 mg/kg) and $\mathrm{N} 15 \mathrm{P}$ was incubated with these PBMCs at $25^{\circ} \mathrm{C}$ in $5 \% \mathrm{CO}_{2}$, for $24 \mathrm{~h}$. PBMCs without naLipoN15P or N15P were used as a negative control, and equal amounts of T20 as anti-HIV drugs were added for the positive control. Each group was detected by flow cytometry after $24 \mathrm{~h}$ incubation. Viral load was detected by real-time polymerase chain reaction (PCR) after $24 \mathrm{~h}$ incubation. The conserved gag and env region was amplified using specially designed primers (forward primer: 5'-AGTGGGGGGAC ATCAGCAGCCATGCAAAT-3', reverse primer: 5'- GCTATGTCAGTTCCC CTTGGTTCTC-3'; primers synthesized by Shanghai Biological Engineering Co. Ltd.), to establish a system for the determination of the viral load of SIV by realtime PCR in each of the following groups: naLipo-N15P-treated, N15P-treated, untreated (blank), and T-20-treated (positive control, a kind of HIV drugs, presented by Nan Yang Central Hospital) . 


\section{Statistical analysis}

All of the data were analyzed using SPSS software, version 17.0. Significant level was set at I $p<0.05$.

\section{RESULTS}

The results of particle size and zeta potential analyses of the nano-liposome showed that particles were circular, and evenly distributed; the mean particle diameter was $80.3 \pm 11.37 \mathrm{~nm}$ and zeta potential was $29.37 \pm 3.30 \mathrm{mV}$; they remained fairly stable after storage in a refrigerator for 1 month. After 4 months of storage at $-20{ }^{\circ} \mathrm{C}$, the encapsulation efficiency remained $56.73 \pm 0.22$. The encapsulation efficiency of naLipo-N15P at $-20{ }^{\circ} \mathrm{C}$ was higher and more stable than at 4 and $25^{\circ} \mathrm{C}(46.65 \pm$ 0.19 and $20.52 \pm 0.17$, respectively).

No chemotactic effect on PBMCs SDF-1a is the only known chemokine that binds to and activates CXCR4. Therefore, we used SDF-1a stimulation of PBMCs as a positive control. The number of migrating cells in the experimental group was divided by the number of migrating cells in the blank control group to calculate the chemotactic index. Compared with control wells, the absorbance values from wells treated with different concentrations of naLipo-N15P were not significantly different $(p>0.05)$. Therefore, naLipo-N15P had little impact on the survival and growth of normal PBMCs. Additionally, different concentrations of naLipo-N15Ps show apparently no toxic effect on PBMCs.

\section{Inhibition of chemotactic activity induced by SDF-1a}

The effects of different concentrations of naLipo$\mathrm{N} 15 \mathrm{P}(0.1,1,10,100$ and $1000 \mathrm{ng} / \mathrm{mL})$ on PBMC activity were analyzed by one-way analysis of variance. The differences among the various groups were statistically significant $(p=$ $0.001<0.05, a=0.05$ ), but there was no difference between the chemotactic index values of each experimental group and that of the blank control group.

We calculated the chemotactic index for each of the tested groups; the chemotactic index for the positive control group was $5.86 \pm 1.15$, whereas the chemotactic indices of the experimental groups were $<2$. From the statistical point of view, a chemotactic index $<2$ denotes the absence of chemotaxis. This result indicated that PBMCs treated with N15P and naLipo-N15P showed no chemotaxis.
The research about the chemotaxic index induced by IL-8, IP-10, I-309, MCP-1, SDF-1 $\alpha$, eotaxin-2, MIP-3 $\alpha$, and MIP-3 $\beta$ indicated that, the naLipo-N15P and N15P inhibited the chemotactic activity induced by SDF-1 $\alpha$ in a dose-dependent manner, but there was no obvious effect on the chemotactic activities induced by the other seven kinds of chemokines. The number of PBMCs exhibiting chemotactic activity induced by SDF$1 \alpha$ obviously reduced upon treatment with the same concentrations of naLipo-N15P and N15P (Figure 1).

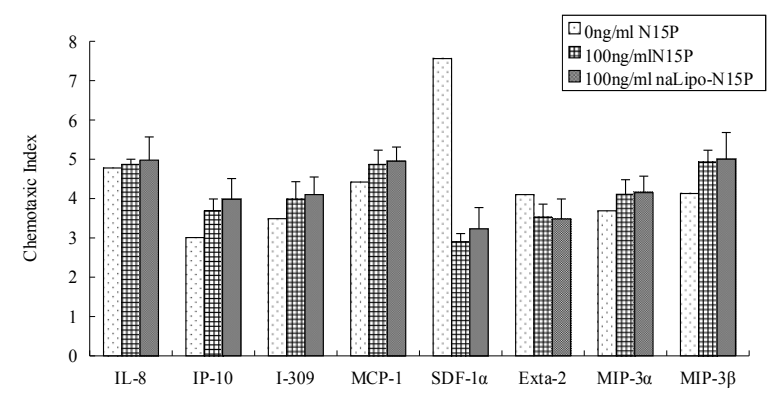

Figure 1 The chemotaxic index induced by IL-8, IP-10, I-309, MCP-1, SDF-1 $\alpha$, eotaxin-2, MIP-3 $\alpha$, and MIP-3 $\beta$

When the concentration of naLipo-N15P and $\mathrm{N} 15 \mathrm{P}$ were $0.1 \mathrm{ng} / \mathrm{mL}$, the cell chemotaxis induced by SDF-1 $\alpha$ was inhibited. The inhibition rate reached $78.88 \%$ when the concentration of naLipo-N15P and N15P were $1000 \mathrm{ng} / \mathrm{ml}$. What's more, the chemotactic index of PBMCs treated with different concentrations of naLipo-N15P and $\mathrm{N} 15 \mathrm{P} \quad(0, \quad 0.1,1,10,100$ and $1000 \mathrm{ng} / \mathrm{ml})$, compared with the control cells, shown that there was no significant differences between the inhibition of SDF-1a-induced chemotactic activity by naLipo-N15P and N15P $(p>0.05)$. By the Reed-Murch method, the half maximal inhibitory concentration $\left(\mathrm{IC}_{50}\right)$ of naLipo-N15P, which plays a role in the chemotactic activities induced by SDF-1a, was calculated as $3.31 \mathrm{pg} / \mathrm{mL}$. The results show that naLipo-N15P can influence the chemotactic activity induced by SDF-1 $\alpha$ in PBMCs in an apparently dose-dependent manner.

\section{Competitive binding of naLipo-N15P to CXCR4}

We used flow cytometry to detect the biological activity of naLipo-N15P with the chloramine T method as previously described [9]. Bound radioactivity was measured using a Wallace counter (Turku, Finland) with $70 \%$ efficiency. Specific binding (Bs) was determined by subtracting nonspecific binding $\left(B_{N S}\right)$ from total binding $\left(\mathrm{B}_{\mathrm{T}}\right)$, and the free ligand concentration was estimated by subtracting the amount of 
bound ligand from the total amount of ligand added. The equilibrium $\mathrm{K}_{d}$ was calculated as the free concentration of radioligand at half-maximal binding, by fitting data to the Hill equation and by linear Scatchard transformation [10].

The data were evaluated by a nonlinear fourparameter logistic model to estimate the $I_{50}$ value (the concentration of competitor at halfmaximal specific binding). The relative binding affinity (RBA) of each competitor was calculated as the ratio of the concentrations of N15P or naLipo-N15P and competitor required to reduce specific radioligand binding by $50 \%$ (ratio of $\mathrm{IC}_{50}$ values). The RBA values of N15P and naLipoN15P were arbitrarily set at 100 . The ChengPrusoff equation was used to calculate the $\mathrm{K}_{\mathrm{i}}$ of the various competitors. The $I_{50}$ can be calculated from the competitive inhibition curve of naLipo-N15P as a CXCR4 antagonist (fig 2-3). The $\mathrm{IC}_{50}$ was $5.01 \mathrm{pM}$, indicating increased competitive inhibition of CXCR4 binding compared to that seen with N15P alone. The competitive binding to SDF-1 $\alpha$ was $1.89 \mathrm{pM}$ and the $\mathrm{K}_{\mathrm{i}}$ was $2.4 \mathrm{pM}$. The $\mathrm{K}_{\mathrm{d}}$ values calculated from the saturation curves were $1.11 \pm 0.21 \mathrm{nmol} / \mathrm{L}$ for PBMCs, and $14.06 \pm 0.89 \mathrm{nmol} / \mathrm{L}$ for SDF-1a. The $B_{\max }$ was $611.1 \pm 0.58 \mathrm{fmol} / \mathrm{mg}$. The results of a saturation ligand binding assay with ${ }^{125}$ I-naLipoN15P show that naLipo-N15P bind with high affinity to membrane receptors on human PBMCs. Further, ${ }^{125}$ I-naLipo $-\mathrm{N} 15 \mathrm{P}$ strongly competed with the CXCR4 binding of ${ }^{125}$ I-SDF-1a in a concentration dependent manner. These results indicate that the inhibition of CXCR4 binding to SDF-1a by naLipo-N15P is as high as that of N15P.

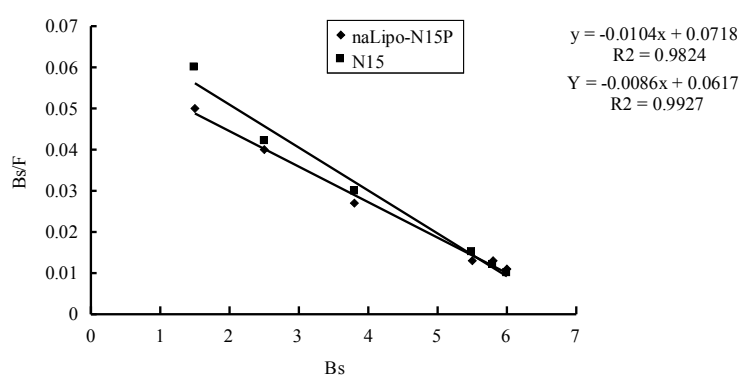

Figure 2: The binding of naLipo-N15P/N15P to the CXCR4 receptor on human PBMCs (Scatchard plot)

\section{Specific binding to CXCR4 on the surface of PBMCs}

Data from the negative and positive control groups indicate the reliability and credibility of this experiment. CXCR4 molecules, labeled with FITC monoclonal antibodies, exhibited green fluorescence on the cell surface when viewed under laser scanning confocal microscopy, indicating that CXCR4 was distributed on the cell

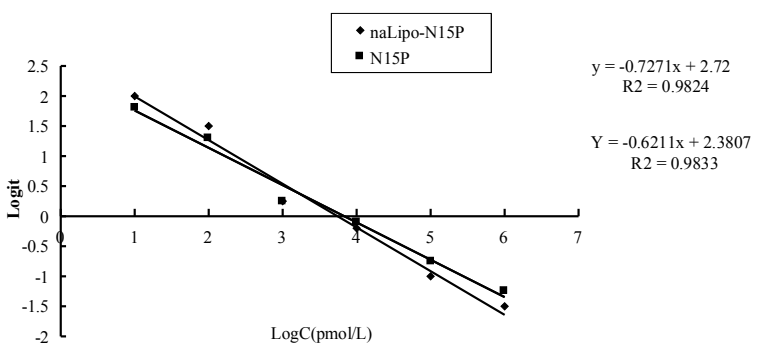

Figure 3: The competitive inhibition curve of naLipoN15P for CXCR4 binding as measured by a saturation ligand binding assay with ${ }^{125}$ I-N15 (Logit plot).

surface. The negative control group (human serum albumin) and the blank control group exhibited linear green fluorescence around the cells, with little fluorescence inside the cell. In the SDF-1a-treated positive control group, CXCR4 was distributed at the cell surface, the linear green fluorescence around the cells was reduced, and the intracellular green fluorescence was higher. The naLipo-N15P experimental group exhibited decreased linear green fluorescence around the cells, and increased intracellular green fluorescence. These data indicate that the cell surface receptor CXCR4 was partially internalized into the cells upon SDF1a stimulation (Fig. 4). Based on flow cytometry and laser confocal detection of receptor internalization, naLipo-N15Ps, in contrast to N15P, not only induce CXCR4 internalization, but also prevent internalized receptors from cycling to the cell surface.

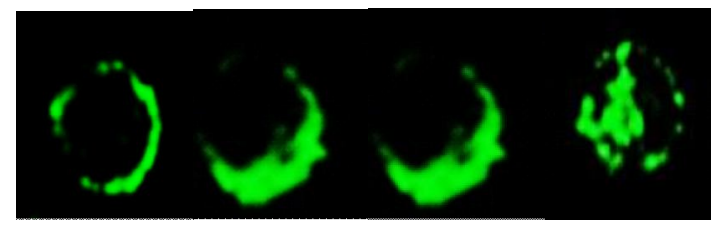

a b c c d

Figure 4: Confocal microscopic images: untreated PBMCs (blank control, a), human serum albumintreated PBMCs (negative control, b), fractalkinetreated PBMCs (positive control, c), and PBMCs treated with naLipo-N15P (experimental group, d)

\section{Targeted distribution of naLipo-N15Ps in vivo}

NaLipo-N15Ps were present at maximal concentrations in blood at $96.75 \mathrm{~min}$, and the concentration was maintained at relatively higher levels for a relatively long period than N15P. The plasma concentration-time curve of naLipoN15Ps indicated that the area under the curve (AUC) of naLipo-N15P (6383.17 $\left.\mathrm{ng} \cdot \mathrm{ml}^{-1} \cdot \mathrm{min}\right)$ was higher than that of N15P (2272.53 $\mathrm{ng} \cdot \mathrm{ml}^{-}$ $\left.{ }^{1} \cdot \mathrm{min}\right)$. The distribution phase half-life of naLipo- 
$\mathrm{N} 15 \mathrm{P}$ was $46.53 \mathrm{~min}$, and the elimination phase half-life was $97.30 \mathrm{~min}$. The distribution phase half-life of N15P was $49.86 \mathrm{~min}$, and the elimination phase half-life was $41.99 \mathrm{~min}$. The speeds of naLipo-N15P and N15P distribution from the central compartment to the peripheral compartment were similar, whereas the difference in elimination speeds was significant. NaLipo-N15Ps accumulated in target tissues, such as the heart, spleen, kidney, liver, lung, and other tissues, particularly in the liver and spleen, and decreased rapidly with time. This observation also indicates that liposome encapsulated drugs have a greater half-life in the circulation, facilitating HIV-targeted drug delivery. By tissue distribution, we found that the drug concentration in the liver rose from $13.26 \pm 1.37$ to $61.41 \pm 1.58 \mathrm{ng} / \mathrm{ml}$, whereas that in the spleen rose from $2.97 \pm 0.11$ to $20.71 \pm 0.32 \mathrm{ng} / \mathrm{ml}$. The concentration of naLipo-N15P also increased in lung tissue.

\section{Blocking the effect on SIV infection of PBMCs}

Following DNA amplification by real-time PCR, the data were analyzed by the system software. A standard curve was generated, with the logarithm of the starting template concentration plotted on the $\mathrm{x}$-axis, and $\mathrm{C}_{t}$ on the $\mathrm{y}$-axis. The regression equation for the standard curve was $y$ $=-2.321 \mathrm{x}+26.752$, with an $\mathrm{R}^{2}$ value of 0.9981 . The standard curve showed a good linear relationship within the range of $10^{1} \sim 10^{4}$ copies. The SIV viral loads in PBMC culture supernatants from the different experimental groups were calculated and expressed as the copy number per milliliter of cell culture supernatant. The actual viral load of the sample was calculated as the detected viral content divided by 0.9 . The $C_{t}$ of each sample was detected by real-time PCR, and the viral load was calculated from the standard curve based on the regression equation. The viral load of the positive control group was $8924 \pm 1036$, while the naLipo-N15P-treated group was $289 \pm 45$, the N15P-treated group was $665 \pm 81$, and the T20 -treated group was $274 \pm 34$. There were significant differences between the viral loads of the two treatment groups and the positive control group; however, no significant differences were seen between the naLipo-N15P-treated and T20-treated groups. These data demonstrate that naLipo-N15P can potentially block SIV infection.

\section{DISCUSSION}

The process of chemokines binding to receptor is as follows. Chemokine moves to the the sites of corresponding receptor. The exposed $\mathrm{N}$-terminus combines with the $\mathrm{N}$-terminus of the receptor to modify it to a minor groove, thus causing overall the chemokine receptor, to become allosteric, and expose the membrane binding site hidden in the transmembrane helix of membrane. The biological effect is exerted after the signal is generated and transmitted into the cells. Studies show that although the chemokines that change or truncate the $\mathrm{N}$-terminus lose inflammatory ability, they can still combine with receptor. Thus they become the corresponding receptor antagonist. Thus, it seems that $\mathrm{N}$-terminal contains a chemokine binding site, thus suggesting that chemokines binding receptor sites constitute a target for drug to bind selectively.

Because vMIP-II can combine with CCR1, CCR3, CCR5 and CXCR4 and other chemokine receptors, and does not cause receptor activation, so we predicted VMIP-II can be used as a blocking agent of these receptors. Therefore vMIP-II can effectively prevent the virus from infecting target cells, by blocking co-receptor CCR5/CXCR4, which undoubtedly provides excellent molecular shape for exploring the design of chemokine receptor antagonist and provided better research to design small molecule anti-HIV drugs by the interaction study of chemokine ligand - receptor.

In the present work, we used a synthetic peptide approach to study the role of the N-terminus of VMIP-II in the recognition and binding of the important chemokine receptor CXCR4. A high positive charge is seen in several peptide and non-peptide inhibitors of CXCR4, such as T20, ALX40-4C, and AMD3100 [11]. However, the utility of these molecules is limited due to poor stability, toxicity, poor targeting in vivo, and other reasons.

In order to improve targeting and stability, enhance the bioavailability of N15P, N15P was encapsulated into liposome. We studied the biological activities of naLipo-N15P by chemotaxis research, reporter binding activities and tissue distribution research, to measure it as CXCR4 receptor antagonist.

Nanoliposomes (small unilamellar vesicles, SUV), is one of the more desirable liposomal pharmaceutical carrier. The specific advantages of stability, absorbability distribution, etc, are why nanoliposomes are employed to encapsulate hydrophilic, hydrophobic and amphiphilic drugs. Sustained-release drugs can play a pharmacodynamic role when they are delivered to target cells. Hence N15P was encapsulated in liposomes to change the distribution of drug in vivo, improve therapeutic index, as well as reduce therapeutic dose and drug toxicity. 
Encapsulated drugs are mainly concentrated in the liver, spleen, lungs and other organs which express high levels of macrophages.

\section{CONCLUSION}

Our study demonstrates that a peptide comprising the first 15 residues of the $\mathrm{N}$-terminus of VMIP-II, encapsulated into liposomes, did not cause chemotaxis in normal human lymphocytes, but could inhibit the chemotaxis of PBMCs caused by a physiological chemokine. Such a peptide encapsulated into nano-liposome could potentially serve as a delivery system for drugs against HIV or inflammatory diseases related to CXCR4 to increase their therapeutic index. We believe that naLipo-N15P, acting as a CXCR4 antagonist, readily accesses sites of high CXCR4 expression. Moreover, naLipo-N15Ps play a biological role by specifically and competitively blocking SDF-1 binding to CXCR4. We envision, therefore, that the CXCR4 inhibitory effect of naLipo-N15P can be exploited in the treatment of advanced AIDS, cancer metastasis, severe anemia, atherosclerosis, and other diseases.

\section{ACKNOWLEDGMENT}

This study was supported by grants from Guangzhou Major Science and Technology Projects (2005Z1-E4081) and Nanyang Qi Wei Microecological Gene Science and Technology Development Co, Ltd. The authors also thank the staff of the Radiological Department of Nan Yang Central Hospital for assistance and suggestions.

\section{REFERENCES}

1. Mayuko Mori a, Dongxiang Liu a, Santosh Kumar a, Ziwei Huang. NMR structures of anti-HIV D-peptides derived from the $\mathrm{N}$-terminus of viral chemokine VMIP-II [J]. Biochemical and Biophysical Research Communications. 2005; 335: 651-658.

2. Rawat SS, Johnson BT, Puri A. Sphingolipids: modulators of HIV-1 infection and pathogenesis[J]. Biosci Rep. 2005; 25(5-6): 329-43.

3. van der Meer P, Ulrich AM, Gonźalez-Scarano F, Lavi E. Immunohistochemical analysis of CCR2, CCR3, CCR5, and CXCR4 in the human brain: potential mechanisms for HIV dementia [J]. Exp Mol Pathol. 2000; 69(3) : 192-201.

4. De Jong LAA, Uges DRA, Franke JP, Bischoff $R$. Receptor-ligand binding assays: technologies and applications. J Chromatogr B. 2005; 829: 1-25.

5. Naiming Zhou N, Luo Z, Luo J, Hall JW, Huang Z. A Novel Peptide Antagonist of CXCR4 Derived from the $\mathrm{N}$ Terminus of Viral Chemokine vMIP-II [J]. Biochemistry 2000; 39: 3782-3787.

6. Vlahakis $S R$, Villasis-Keever $A$, Gomez $T$, Vanegas $M$, Vlahakis N, Paya CV. G protein coupled chemokine receptors induce both survival and apoptotic signaling pathways. J Immunol 2006; 169: 5546-5554.

7. JinNan University Ethical Committee in accordance with "Principles of Laboratory Animal Care. NIH publication no. 85-23, revised 1985

8. Majka M, Ratajczak J, Kowalska MA, Ratajczak MZ. Binding of stromal derived factor-1alpha (SDF1alpha) to CXCR4 chemokine receptor in normal human megakaryoblasts but not in platelets induces phosphorylation of mitogen-activated protein kinase p42/44 (MAPK), ELK-1 transcription factor and serine/threonine kinase AKT. Eur $J$ Haematol 2010; 64: 164-172.

9. Kijowski J, Baj-Krzyworzeka M, Majka M,Reca R, Marquez LA, Christofidou Solomidou M, JanowskaWieczorek A, Ratajczak MZ. The SDF-1-CXCR4 axis stimulates VEGF secretion and activates integrins but does not affect proliferation and survival in lymphohematopoietic cells. Stem Cells 2001; 19: 453-466.

10.Bailey, G. S. In vitro labeling of proteins, in Radioisotopes in Biology, IRL, Oxford, UK. 1990: $191-205$.

11. Sun $H$, Mo $X$, Yan L, Li X, Zhang G. Anti-HIV-1 Activities of rVMIP Combined with other Drugs by Real-time Polym erase Chain Reaction. Chin Pharm J, 2010; 11(45): 814-817. 